\title{
If A Marketer Teaches Ethics, Is There Still A Sound? The Interdisciplinary Case
}

\author{
Jim Murrow, (Email: jmurrow@drury.edu), Drury University
}

\begin{abstract}
When a marketer teaches general ethics courses, widespread ontological shock can result on campus. A case for positive paradigm expansion of all involved persons in an interdisciplinary environment is made. Suggestions for specific interdisciplinary opportunities and applications are provided. A call for interdisciplinary efforts is made and supported. Teaching outside your field is always chancy but when your terminal degree is marketing and the courses outside the area of expertise you are asked to teach are general distribution courses in ethics, cross-listed as Philosophy, it might be more than chancy, it may be ridiculous according to the received view. Reactions from colleagues in the business school may (and did) range from puzzlement to high hilarity particularly if one has been successful in business "in the real world" as was the case in this instance. Other colleagues seem to experience ontological shock as if they have suddenly found themselves in an alternate universe where "up" is "down." This report is about doing the academically strange thing of teaching across the curriculum and enjoying it. But wait, there's more, and even greater heresy! This will urge others in professional schools, sciences and other disciplines to consider the idea; and then do it, for all-around "wins" for all involved.
\end{abstract}

\section{THE BEGINNING}

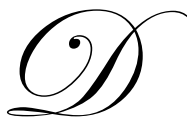

rury University was founded in Springfield, Missouri in 1873, in an area with little ethnic or religious diversity in the middle of the contiguous USA, as a church related liberal arts college. And, that still pretty well describes where Drury University is still located. About ten years ago (in 1995), the faculty of Drury University revised the curriculum to reflect the growing need to bring our students a much needed global orientation. Global Studies courses were created to provide a minor in Global Studies for each Drury graduate. Then the Academic Dean began to search for people willing to teach those courses and was specifically interested in having representatives from all disciplines in the instructor mix. He leaned fairly strongly on the department chairs as Deans sometimes can do, with success since budgets and new faculty lines are mentioned in passing in such discussions. Personally, it seemed a good step for tenure, so I signed on to take the "Ethics and Philosophers for Dummies" (not the real name) course that was provided by the Dean and Philosophy Department in the summer. The Philosophy instructor /colleague was outstanding and we had a diverse mix of participants with terminal degrees in physics, business and mathematics as well as English and language professors spending the summer studying and discussing the course content for Values Analysis (GLST 210).

It was a wonderful opening of the unknown (but rumored) world of diverse philosophy and ethical thoughts for me. As a chemist then an MBA, Philosophy was not part of my education. Not until after a 20 year business career and a golden opportunity for the Ph.D. did I ever come in contact with philosophy, paradigms and ontology. It was a new world, and I liked it.

As my office bookcase began to hold books on ethics, philosophers and religious writers; colleagues who dropped in for gossip, questions or selling tickets, cookies, candy and assorted collections for their children or charities were very curious about why a marketer in the business school would have use for those books? Thankfully, 
W.C. Fields had paved the way for me when he was caught reading the Bible, so I simply used his response of just, “...looking for loopholes.” It seemed to be an entirely acceptable and believable response.

\section{THE GENERAL CASE FOR DIVERSITY}

Diversity works to improve lives and will work on a personal, local and national stage. Jarod Diamond's book, Guns, Germs and Steel, won the Pulitzer Prize and described the reasons why some areas and populations progressed and others did not throughout earth's history. Explaining the reason why China with a highly developed civilization and sophistication centuries before Europe's citizens lifted their collective knuckles from the ground, did not explore, conquer and create technology to do those things long before and instead of European nations, Diamond opines it was the lack of diversity (competition and control of ideas) in China compared to Europe. Diversity and competition as key drivers of progress is a recurring theme in this fascinating and seminal work and his revisit to those themes in 2003 only supported the case for diversity even more strongly.

On an organizational basis, such leadership gurus as Lawrence Crosby (2005) advocate diversity in the form of cross-functional teams for real success in organizational enterprises. And, they have the research to back it up. Such success stories include Microsoft as well as other giants that also dance well to the fast music of technological changes.

Rudolph Marcus (1992), a technology transfer consultant wrote of his experiences with blending traditional Western and Japanese science to yield better science. Western science is: goal-oriented, short-term, uses thought experiments and is language precise. The Japanese way of science is: holistic, process-oriented, uses physical experiments only, is multi-valued, has long-term emphasis and is expressed in ideograms (with interpretation). Diversity brings challenges, but the benefits of diversity when working together is increased and improved knowledge flow according to Marcus.

John Pepper, CEO of P\&G, is quoted by Tolbert (2004) as saying that the success of P\&G: "is a direct result of our diverse and talented workforce. Our ability to develop new consumer insights and ideas and to execute in a superior way across the world is the best possible testimony to the power of diversity any organization could ever have.” That seems strong support.

For me, the payoff has been to have a new language with which to converse with students, colleagues and businesses about the ways to be successful in business and life. I am strong in the knowledge that doing good is really good business and that it always has been true as long as business has been transacted between people. And, I try to make that point with students in my business classes.

\section{Application: What Is Specifically Done?}

Most students will have to make a living and that means business and that means they will confront business moral dilemmas. All Global Studies Values Analysis courses at Drury use the same business case to pre and post-test in our classes. Also, in my classes we address a juicy business case that spurs differences of opinion and support for the positions held and opens up applications to the student's lives. The case is about a love affair within a business setting filled with adultery, right to privacy, duty to spouse and firm, CEO's duty to employees, employee's duties as moral agents, happiness and greatest good questions. Formal and informal writings in my class include the usual suspects of abortion, euthanasia, environmental readings and discussions but the real fun begins with debates.

Debates on subjects dealing with moral questions and defining the right thing are chosen by students themselves as well as consisting of targets of opportunity within the environment. This last semester we had such an "environmentally derived" opportunity with Professor Ward Churchill and his "little Eichman" comments about "facilitators" in the twin towers on 9/11. First, of course we had to bring the students up-to-speed on who Eichmann was and his role in the holocaust during WWII. The path of thinking developed through debate by students went from rabid indignation to understanding Churchill's (and Eichmann's as well) view, to support of Churchill's right to say what he thinks as a fundamental right. It was a slippery \& precarious journey for many, but well worth the effort. 
Students are continually reminded that if they (or I) leave class without a headache, we haven't done our job of thinking hard about difficult questions well enough. Student response to the course indicates we accomplish our goal more often than not.

\section{Location: Advantages And Otherwise}

Springfield, MO., is often called the "Bible Belt, Buckle." World headquarters of The Assemblies of God (AG) are located there along with many large and active churches of more fundamentalist Christian outlook. Many Drury students are citizens of the area and accordingly, we experience (and welcome) many faith based literalist arguments in class. Often it is students who bring up the Council of Nicea, and startle many not fully informed about the history of the Christian church. Paradigm shifts are rare and are not the goal of the class. The goal is rather to foster better understanding, tolerance and (if we're lucky) paradigm expansion with the achievement of inclusiveness and as an occupant of mandala. Mandala is used as an exercise (what/who has moral standing and is located within the circle and what/who is outside?) during the first part of the course and again at the end of the course.

Generally, students exhibit more inclusiveness at the end for groups and other entities, but not always. Often professors make the final cut and are included as well...but again, not always. An excerpt from the course syllabus (that I lifted....with permission...from my Philosophical guru and colleague, Dr Charles Ess) may help define more closely what we do and why.

What is Values Analysis?

Outcomes: Values Analysis seeks to:

- $\quad$ Develop an understanding of and ability to apply diverse models of ethical decision making;

- $\quad$ Develop a commonly shared language and set of conceptual skills, including logical and critical thinking abilities for analyzing values issues;

- $\quad$ Help students recognize the validity of diverse approaches to ethical decision-making;

- $\quad$ Help students assume personal responsibility for their own value system, and

- $\quad$ Help students make explicit the relationship between personal responsibility and participation in a democratic society.

We will examine several value sets as well as our own value set and its origin.

Content: Values Analysis will include study and discussion of:

- $\quad$ Logic and critical thinking;

- $\quad$ Ethical relativism, dogmatism, and pluralism;

- $\quad$ At least three ethical theories representative of Western traditions; and

- At least one alternative theoretical approach (feminism, non-Western approaches, etc.).

This collection of critical thinking skills and theory is then applied to current ethical issues in a variety of contexts, e.g., medicine, the environment, sexuality, business, etc.

\section{Guidelines For Discussion}

Listen before we agree or disagree. Virtually every viewpoint deserves a hearing.

Welcome differences and use conflict.

When others disagree with you, take the disagreement not as a personal attack on your views; rather, consider the probability that the other person's viewpoint arises from experiences and thought which you have not had. Disagreement means first of all the opportunity to learn about experiences and thought different from your own. 
Learning about different experiences and thought often serves to help you understand your own experiences and views more clearly.

When disagreements arise, work through the following checklist:

- $\quad$ Separate the view that is expressed from the person who is expressing it. Be clear that your disagreement is with a viewpoint - not with the person's identity.

- $\quad$ Ask what evidence or arguments might support that position? People often believe what they believe for some good reason. What might these reasons be?

- $\quad$ Take seriously the possibility that your view might be less correct than the one you disagree with. Is it possible that in fact there are better arguments and stronger evidence for the view you disagree with?

- $\quad$ Think seriously about how your view and the other view might both be correct or compatible, rather than opposites or incompatible. Frequently we assume that a difference of views must mean that they necessarily exclude one another; but frequently, it turns out, different views may complete one another. other position.

Only after you have gone through these four steps should you raise your objections or disagreements with the No put-downs of others will be tolerated. That includes the instructor as well!!

Putting down another person because they disagree with you -- most frequently, by ridiculing them or the view they have expressed -- is a common way of seeking psychological satisfaction in the face of the threat they represent to your own viewpoint. To respond to disagreement with put-downs may save you the labor of thinking things through, and the pain of having to admit that you may be wrong -- but it also will guarantee your closedmindedness and destroy any possibility of discussion. Silence and closed minds are not the point of liberal arts education.

The part about the instructor not being allowed "put-downs" was a tough, personal addition, but I admit to a tendency toward being a "smart-aleck" (or worse) at times in an attempt at humor. It shuts down student trust and openness like slamming a door.

\section{Take The Plunge - The “Water” Is Fine}

Calling all Physicists, Biologists, Chemists, and mathematicians; all sciences and disciplines! We can all enrich our own outlook and the outlook and understanding of students by teaching outside our discipline in lower rank classes such as beginning ethics after suitable orientation by our expert colleagues within the topics. Then, diversity happens with all it's value.

Books by scientists are rich in ethical and spiritual insight in the hands of those who know the subject. For example, The Tao of Physics by Fritjof Capra, The Dancing Wu Li Masters; An overview of the New Physics by Gary Zukav or The Elegant Universe: Superstrings, Hidden Dimensions and the Quest for the Ultimate Theory by Brian Greene, are all books by Physics masters that also raise and sometimes address powerful metaphysical questions.

In Biology, The Lives of a Cell: Notes of a Biology Watcher, by Lewis Thomas and the stem-cell research and on-going controversy are great grist for discussions and learning. In Chemistry: the parallels of human sexual behavior and "personality of atoms" and molecules and catalysts all lend themselves to application in discussions about the nature of life. The pursuit of happiness might be our highest human goal and the happiness research in Psychology can certainly add to that discussion as can the book; Molecules of Emotion: The Science Behind MindBody Medicine by Candace B. Pert. Another couple of approaches to a metaphysical topic based in science are the presence of hydrogen in the universe and using the logic of entropy to support a beginning of our universe.

Biologists, Anthropologists, Psychologists and Geologists can all bring in a wide variety of examples into a class such as mine, of behaviors and facts that indicate patterns and ways of thinking and the accompanying moral 
questions...like the ants that farm fungus and then use it to trap much larger creatures for food. Or, the fact that primates can learn language and then teach it to other primates; all are teaching moments/opportunities to broaden and enrich ethical outlooks and moral awareness symbiotically. And then there are mathematicians who could produce "thinking headaches on demand" by explaining chaos applications to causal chains in ethical situations.

That sort of interdisciplinary activity would be potential for paradigm expansion of the finest levels for our students, us and our global communities within which we work and live our lives. And, we should do it because it is the right thing....and great fun.

\section{REFERENCES}

1. $\quad$ Crosby, L.; \& Johnson, S. (2005), Return on Insights, Marketing Management, (May-June) 14-15.

2. Diamond, J. (1999), Guns, Germs, and Steel; The Fates of Human Societies. W. W. Norton, NY.

3. Marcus, R. J. (1992), Harvesting the Advantages of Cultural Diversity, $R \& D$ Innovator, vol. 1,No. 4

4. Tolbert, R. T. (2004), Gaining Competitive Advantage: The Case for Diversity, Retrieved from www.diversityresources.com

\section{NOTES}


NOTES 